九州大学学術情報リポジトリ

Kyushu University Institutional Repository

\title{
Notes on Maltypus ryukyuanus Wittmer (Coleoptera : Cantharidae), with a New Distributional Record in Japan
}

Takahashi, Naoki

Institute of Biological Control, Faculty of Agriculture, Kyushu University

https://doi.org/10.5109/2694

出版情報: ESAKIA. 44，pp.191-198，2004-03-31. Entomological Laboratory，Faculty of Agriculture, Kyushu University バージョン：

権利関係 : 


\title{
Notes on Maltypus ryukyuanus Wittmer (Coleoptera: Cantharidae), with a New Distributional Record in Japan
}

\author{
Naoki TAKAHASHI \\ Institute of Biological Control, Faculty of Agriculture, Kyushu University, \\ Fukuoka, 812-8581 Japan
}

\begin{abstract}
A malthinine cantharid species, Maltypus ryukyuanus Wittmer, is redescribed and illustrated based on the holotype and additional material. It is also recorded, for the first time, from Miyako Island of the Ryukyus, Southwest Japan.
\end{abstract}

Key words: Maltypus ryukyuanus, Malthininae, Cantharidae, redescription, Japan.

\section{Introduction}

The malthinine genus Maltypus comprises about 90 species at present and has characteristic general appearance, such as tiny stoutish body and rather abbreviated elytra with swollen parts along the apices. Most congeners are distributed in the Oriental Region, and several species are recorded from the adjoining areas in the Palaearctic and Australian Regions. In Japan, only one species, Maltypus ryukyuanus Wittmer, has been known to occur in the Yaeyama Group of the Ryukyus and also in the adjacent island, Taiwan. Except for these distributional records (Wittmer, 1984; Takahashi, 1996), little information has been available for this species, since it was originally described by Wittmer (1970). In the present paper, this species is redescribed together with its new distributional information.

\section{Materials and Methods}

Most materials used in this study were dried specimens. Some wet materials fixed and stored in $80 \%$ ethanol were also examined. Methods for measurements of the body structure, detailed examination and illustration of the terminalia follow Takahashi (2001, 2003). The abbreviations for depositories of the materials employed herein are as follows: ELEU (Entomological Laboratory, Ehime University, Matsuyama); ELKU (Entomological Laboratory, Kyushu University, Fukuoka); KURA (Kurashiki Museum of Natural History, Kurashiki). Other materials are stored in my personal collection 
unless specified.

\section{Genus Maltypus Motschulsky}

Maltypus Motschulsky, 1859: 61; Wittmer, 1957: 31; Brancucci, 1980: 310. Type species: Maltypus niger Motschụlsky, 1859, subsequently designated by Delkeskamp (1977).

Falsomalthodes Pic, 1924: 28. Type species: Falsomalthodes testaceonotatus Pic, 1924, by monotypy.

\section{Diagnosis.}

Male.

Body elongate but somewhat stout, and densely covered with pubescence; antennae also provided with intermingled longish pubescence in addition to primary pubescence and particularly so on basal segments, tibiae and tarsi covered with suberect pubescence; elytra fringed with setae in posterior halves at sides.

Head oval in outline in dorsal view, broader than long, gently convex dorsad, weakly depressed apicad before antennal pits and particularly so in front of them, subtruncate with a small notch in the middle or obtusely emarginate but arcuate on both sides at apical margin of clypeus, and gradually narrowed posteriad behind eyes; surface rather smooth; antennae filiform, 1st segment subclavate, 2nd to 10th subcylindrical but relatively short and stout, and 11th subcylindrical and tapered distad around apex; eyes relatively small, semiglobular, and slightly prominent laterad; mandible provided with an acute tooth on mesal margin; gular sutures widely paired and somewhat indistinct.

Pronotum subquadrate, gently convex dorsad, subtruncate but arcuate on both sides at anterior margin, obliquely truncate or provided with a lobe and more or less prominent at front angle, gently arcuate and weakly marginate at posterior margin, obtuse or obtusely rounded at hind angle, and constricted just behind front angles at sides.

Elytra abbreviated, reaching around 6th abdominal tergite, slightly narrowed in posterior halves, sometimes dehiscent in medio-posterior parts, separately rounded at apices, marginate at mesal and lateral margins, and swollen around apices; surface relatively shiny but irregularly and distinctly punctate in most part, and somewhat granulose in posterior parts along lateral margins. Hindwings extending over elytral apices; veins $\mathrm{Cu}$ and $\mathrm{A}$ absent.

Eighth abdominal sternite relatively flat, and incised in the middle or bilobate at apical margin in many cases; 9th reduced. Male genitalia oval in outline in many cases and reduced in various parts; lateral lobes more or less fused with basal piece; processus laminae basalis and median lobe recognized. 


\section{Female.}

Almost similar to male, but body somewhat stouter, antennae shorter, and eyes somewhat smaller. Eighth abdominal sternite often deeply incised in the middle at apical margin. Female terminalia: coxite small; paraproct semicylindrical and developed; small sclerite recognized above coxites.

Distribution. Palaearctic, Oriental, and Australian Regions.

\section{Maltypus ryukyuanus Wittmer, 1970 \\ (Japanese name: Ryûkyû-chibi-jôkai)}

(Figs. 1-8)

Maltypus ryukyuanus Wittmer, 1970: 24; Wittmer, 1984: 164, fig. 124 (new to Taiwan); Satô, 1985: 117, pl. 19, fig. 25; Takahashi, 1996: 6 (new to Iriomote Is.); Takahashi, 1998: 46 (in list).

\section{Redescription.}

Malle.

Body and genitalia almost brownish orange but dusky at apices of genitalia; head somewhat darker; antennae except for a few basal segments, pterothoracic sterna and pleura darker; venter dark brown with yellowish intersegmental membranes; eyes black; apical halves of mandibles and tarsal claws reddish.

Body slightly stout, mostly covered with brownish pubescence; anterior part of head around clypeus sparsely covered with paler longish pubescence.

Head broader than long, 0.99-1.08 times as wide as pronotum, faintly flattened before vertex, subtruncate but faintly emarginate in the middle and arcuate on both sides at apical margin of clypeus; surface rather smooth and shiny; eyes prominent laterad, the interocular distance 2.83-3.45 times as long as transverse diameter of an eye; antennae filiform but somewhat stout on each segment, slightly extending over apices of elytra, 1 st segment subclavate, 2 nd to 11th subcylindrical but tapered distad around apex of 11th, faintly constricted at each base of proximal segments, obscurely transparent in a small spot on each ventral side of 4th to 10th segments (observable in wet material), and relative lengths of antennal segments from base as follows:- 18.8: 11.5: 11.1: 13.0: 13.9: $13.1: 13.1: 12.9: 12.7: 11.5: 16.2$.

Pronotum subrectangular and 1.42-1.49 times as wide as long; disc weakly convex dorsad but faintly flattened in basimesal area, relatively shiny but somewhat mat in lateral parts on surface, subtruncate but gently arcuate on both sides at anterior margin, obliquely truncate and feebly warped dorsad at front angles, arcuate and weakly marginate at posterior margin, obtuse or obtusely rounded at hind angles, constricted 
just behind front angles and slightly dilated posteriad at sides. Scutellum triangular, almost flattened and somewhat mat on surface.

Elytra 1.77-1.79 times as long as wide; surface shiny but slightly mat in swollen parts.

Ventral side of body relatively shiny on surface; 8th abdominal sternite (Figs. 5-6) subrectangular, feebly convex medio-ventrad but depressed in mesal part on surface, explanate and slightly arcuate at sides, obtusely rounded at apical angles, and subtruncate with a deep notch in the middle at apical margin in ventral view.

Male genitalia (Fig. 7) oval in outline; processus laminae basalis remarkably short; basal piece gently convex ventrad; lateral lobes almost fused with basal piece, convex dorsad but somewhat flattened on dorsal surface and bilobed with round tips in apical parts; median lobe finely tubular, relatively short, and projecting from basimesal part of

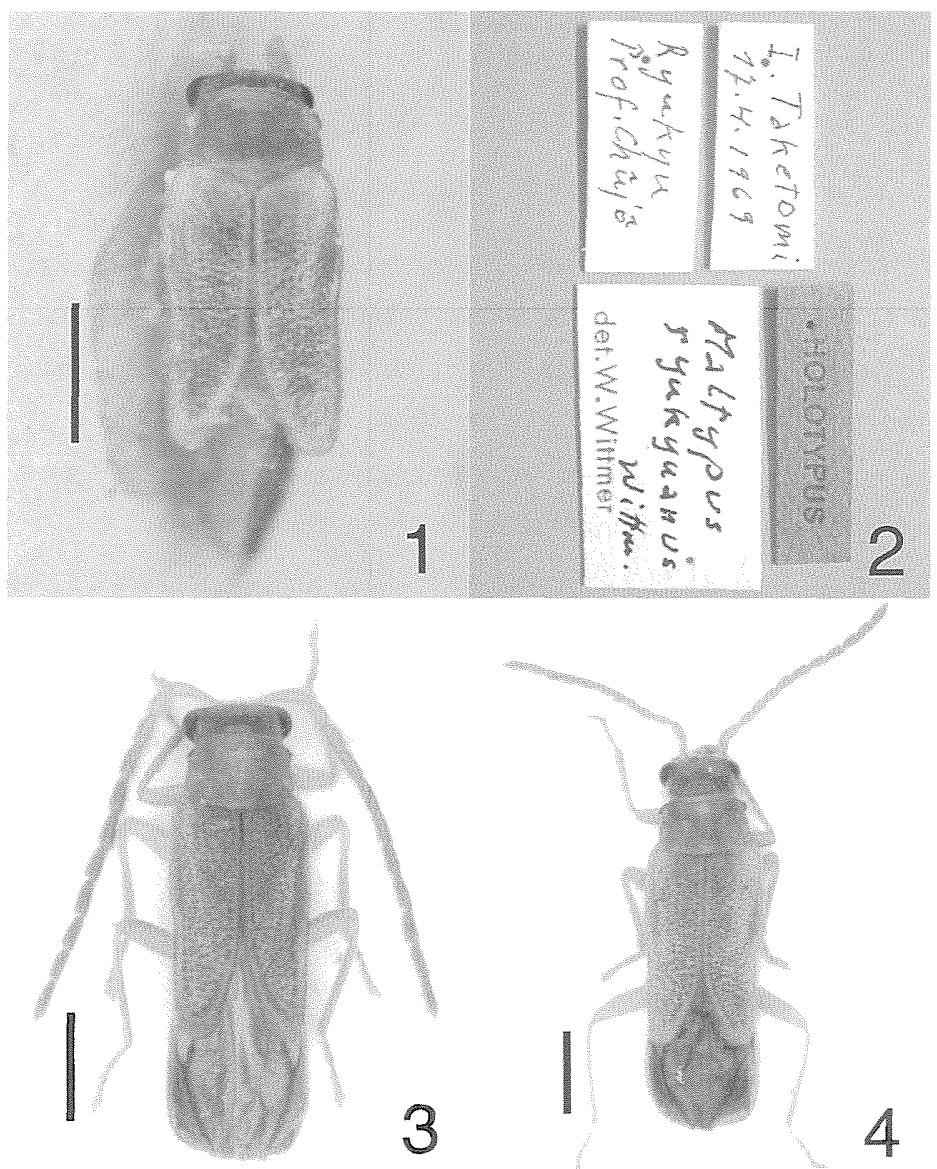

Figs. 1-4. Habitus of Maltypus ryukyuanus Wittmer. 1: Holotype, female; 2: type labels; 3: male; 4: female. Scales: $0.5 \mathrm{~mm}$. 
the flattened apical area.

Length of body: 1.6-1.9 mm; width of body: 0.6-0.7 mm.

\section{Female.}

Almost similar to male, but body slightly stouter, and 8th abdominal sternite dusky. The interocular distance 3.42 (in the holotype; range 2.96-3.86) times as long as transverse diameter of an eye. Antennae shorter, slightly extending over basal halves of elytra, without any transparent spots on surface, and relative lengths of antennal segments from base as follows:- 18.0: 9.8: 7.4: 8.1: 8.5: 8.4: 8.7: 8.9: 8.2: 8.6: 12.1 . Pronotum $1.48(1.42-1.49)$ times as wide as long and $1.12(1.07-1.12)$ times as wide as head. Elytra 1.76 (1.66-1.76) times as long as wide. Eighth abdominal sternite com-

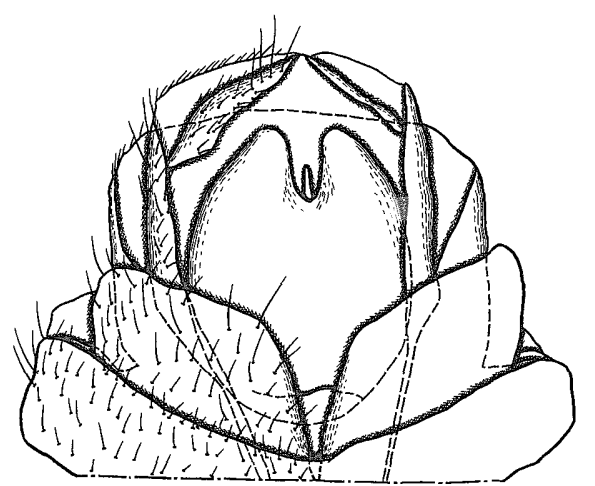

5
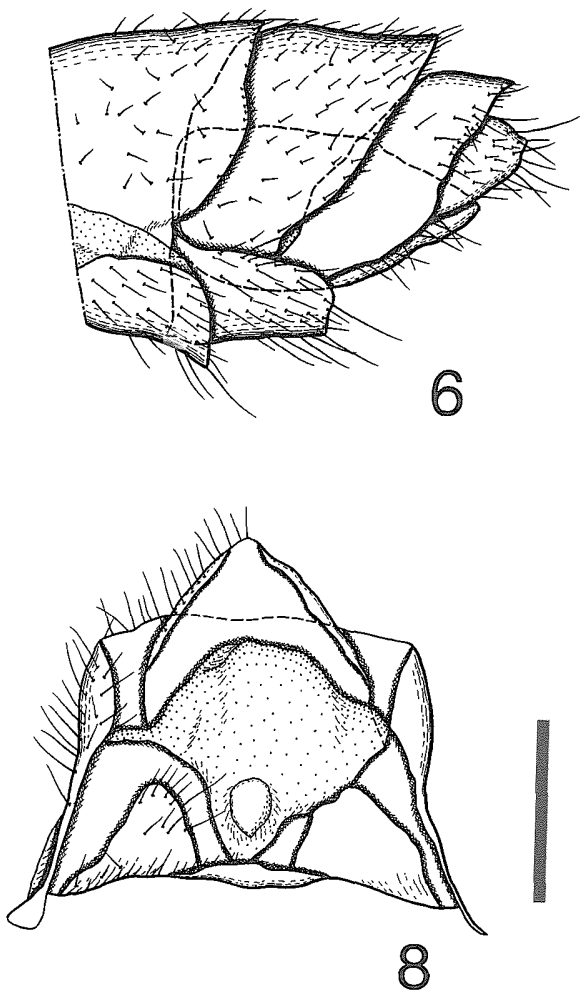

Figs. 5-8. Maltypus ryukyuanus Wittmer. 5-6: Apical portion of male abdomen (5, ventral view; 6, lateral view); 7: male genitalia, dorsal view; 8: female terminalia, ventral view. Scale: $0.125 \mathrm{~mm}$ for Figs. 5-6; $0.1 \mathrm{~mm}$ for Figs. 7-8. 
posed of two sclerites which are connected with a membrane at each basimesal part; each sclerite nearly trapezoidal, narrowed apicad, gently arcuate mesad and sometimes with a faint angulation in the middle at mesal margin, obtusely rounded at apico-mesal angles, weakly convex latero-ventrad in basal part and somewhat flattened in apical part on surface. Female terminalia (Fig. 8): paraproct semicylindrical, dilated basad in basal half, and subtruncate at apical margin; coxite small, reaching around basal half of paraproct, somewhat linguiform but dilated basad and particularly so in basilateral part, with a small triangular lapel in basimesal part; small cylindrical sclerite projecting between coxites; proctiger semicylindrical but tapered apicad, and slightly exceeding apical margin of paraproct.

Length of body: 1.9 (1.6-2.0) mm; width of body: $0.7(0.7-0.8) \mathrm{mm}$.

Type material examined. Holotype (Fig. 1-2), female, "I. Taketomi/ 17.4.1969 [white rectangle with handwritten words]"; "Ryukyu/ Prof. Chûjô [white rectangle with handwritten words]"; "HOLOTYPUS [red rectangle and typed]"; "Maltypus/ ryukyuanus/ Wittm./ det.W.Wittmer [white rectangle with handwritten words except for the bottom line typed]" (deposited in ELEU).

Additional material examined. [Ryukyus] (Miyako Is.) 1 female, Botanical Garden, 28.iv.1989 (A. Yoshida, ELEU); 1 male, 18.iii.1997 (N. Takahashi); 1 female, Mt. Nobaru, 22.iii.1993 (Y. Okushima, KURA); 1 female, 15. iii.1997 (N. Takahashi); 2 males and 3 females, 16.iii.1997 (N. Takahashi); 3 females, Ônosanrin, 23.iii.1993 (Y. Okushima, KURA). (Ishigaki Is.) 3 males and 1 female, Takeda-rindô, 15.iv.1996 (N. Takahashi); 1 male, 17.iii.1998 (N. Takahashi). (Iriomote Is.) 1 male, Monbanare, 3.iv.1994 (N. Takahashi); 2 males, $10 . i v .1996$ (K. Yoshizawa); 1 male, Yutsun Riv., 5.iv.1994 (N. Takahashi); 1 male and 3 females, 18.iv.1995 (N. Takahashi); 4 males and 1 female, $20 . i v .1995$ (N. Takahashi); 1 male, Aira Riv., 16.iv.1996 (N. Takahashi); 2 males and 1 female, near Nadara Riv., 14.v.2003 (T. Nakata, KURA).

Non-Japanese material examined. [Taiwan] 1 male and 1 female, Yangmingshan, Taipei Hs., 25.v.1965 (Y. Miyatake, ELKU); 2 females, Juisui, 2.vi.1980 (H. Makihara, ELKU).

Distribution. Japan (Ryukyus: Miyako Is., Ishigaki Is., Taketomi Is., and Iriomote Is.); Taiwan. (Miyako Island representing new record.)

Remarks. Most specimens were collected by sweeping grasses in shaded places along rivers or streams on Ishigaki Island and Iriomote Island.

Morphological differences were obscure in general appearances within the specimens examined in this study. However, the male genital configuration of the Taiwanese specimen is slightly different from that of the Japanese specimen. Under dry conditions, the former has a mesally curved apical part of the lateral lobe with a subtly angulate and stout apex. Further investigation is required to confirm the variations when sufficient 
specimens are obtained from Taiwan.

Only one species of this genus has been known from Japan until today. This species was originally described from Taketomi Island and Ishigaki Island of the Ryukyus in 1970. Thereafter, it was recorded from Taiwan in 1984 and from Iriomote Island of the Ryukyus in 1996. Additional specimens of this species were collected from Miyako Island in the course of this study. These collecting records suggest that this species is distributed widely in the southern Ryukyus.

\section{Acknowledgments}

This paper is dedicated to Prof. Junichi Yukawa in commemoration of his retirement from Kyushu University. I wish to express my gratitude to Prof. J. Yukawa (ELKU) for his critically reading of the early draft and to Dr. H. Kojima (Kyushu Univ. Museum) for his kind help in various ways. I am also grateful to Prof. M. Takagi and other staff (Institute of Biological Control, Kyushu Univ.) for their encouragement. My thanks are extended to Dr. M. Satô (Aichi) who allowed me to examine the type specimen and an additional specimen for this study, to Drs. Y. Okushima (KURA), K. Yoshizawa (Hokkaido Univ.), and T. Nakata (Okinawa) for their kindness in offering the invaluable material.

\section{References}

Brancucci, M., 1980. Morphologie comparée, évolution et systématique des Cantharidae (Insecta: Coleoptera). Ent. basil., 5: 215-388.

Delkeskamp, K., 1977. Cantharidae. In Wilcox, J.A. (ed.), Coleopterorum Catalogus Supplementa, pars 165, fasc. 1.485 pp. W. Junk, The Hague.

Motschulsky, V., 1859. Insectes des Indes orientales. Etud. Ent., 8: 25-118.

Pic, M., 1924. Coléoptères exotiques en partie nouveaux. Échange, Moulins, 39: 27-28.

Satô, M., 1985. Cantharidae. pp.107-119, In Kurosawa, Y. et al. (eds.), The Coleoptera of Japan in Color, 3. Hoikusha, Osaka. (In Japanese.)

Takahashi, K., 1998. Check-list of Cantharidae of Japan. Kanagawa-Chûhô, Odawara, (122): 29-48. (In Japanese.)

Takahashi, N., 1996. [First record of Maltypus ryukyuanus from Iriomote Island.] Coleopt. News, (114): 6. (In Japanese.)

Takahashi, N., 2001. Taxonomic study of the genus Malthodes from Japan (Coleoptera: Cantharidae) I. Discovery of new species in the Nansei Islands, Southwest Japan. Ent. Sci., 4: 89-108.

Takahashi, N., 2003. Description of a new species of the genus Malthodes (Coleoptera, 
Cantharidae) from Shikoku, southwest Japan. Spec. Bull. Jpn. Soc. Coleopterol., (6): 283-288.

Wittmer, W., 1957. 20. Beitrag zur Kenntnis der indo-malayischen Malacodermata (Col.). Mitt. schweiz. ent. Ges., 30: 25-47.

Wittmer, W., 1970. Cantharidae und Malachiidae von den Inseln Okinawa und Ryukyu, gesammelt durch Herrn Prof. Dr. Michio Chûjô (46. Beitrag zur Kenntnis der palaearktischen Cantharidae und Malachiidae). Mem. Fac. Edu. Kagawa Univ., 2 (192): 22-27.

Wittmer, W., 1984. Die Familie Cantharidae (Col.) auf Taiwan (3. Teil). Ent. Rev. Japan, 39: 141-166, pls. 4-9. 